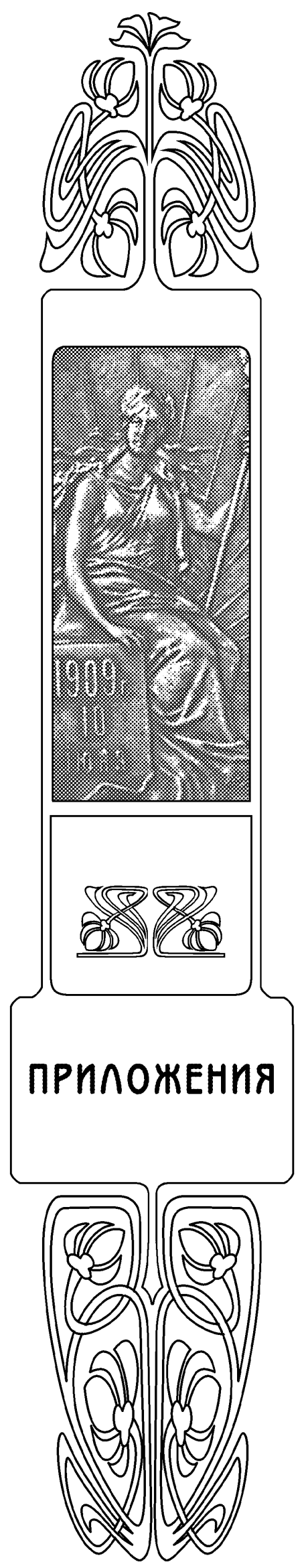

PERSONALIA

\title{
ЕЛИЗАВЕТА ВСЕВОЛОДОВНА МИРОНОВА (К девяностолетию со дня рождения)
}

Елизавета Всеволодовна Миронова родилась 20 сентября 1920 года в Тамбовской области. Ее детство прошло в Сосновском лесничестве. Отец, Всеволод Александрович Петэн, имел два высших образования и владел, кроме русского, украинским, немецким, английским и французским языками. Мама, Клавдия Васильевна Добрицкая, была из духовного сословия, окончила Институт благородных девиц.

Выпускница географического факультета Московского областного педагогического института (1941 г.) Е.В. Миронова в 50-е годы заведовала кафе-

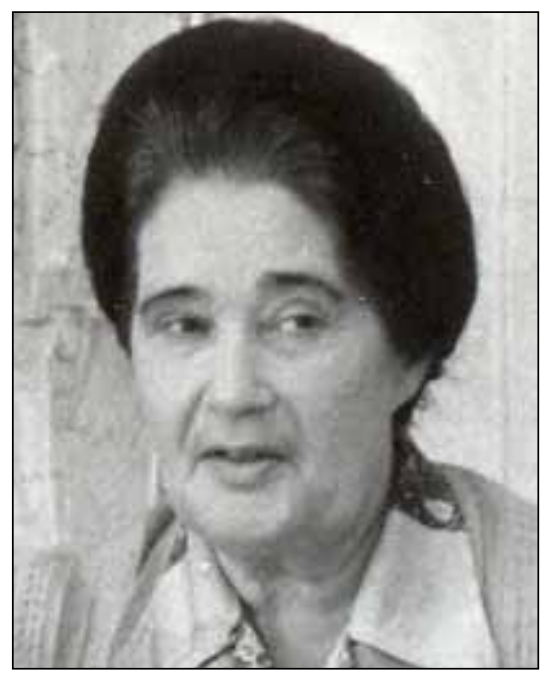
дрой экономической географии в

Черновицком университете (ЧГУ). В этот период она проводила исследования Станиславского района, занималась историей её развития хозяйства и сельского населения Черновицкой области, кооперативной промышленности г. Черновцы, изучением сельского хозяйства Англии.

С 1959 года Елизавета Всеволодовна работала на географическом факультете Саратовского государственного университета, где возглавляла кафедру экономической географии вплоть до 1972 года.

Научные интересы Е.В. Мироновой были широки и многообразны. Основные направления ее научных исследований - вопросы мировой и отечественной географии, территориальные аспекты населения, трудовые ресурсы, социальная инфраструктура в сельской местности, проблемы анализа факторов размещения сельского хозяйства, его интенсивности, территориальной организации сельского хозяйства и основных этапов его развития, аграрные отношения в Великобритании.

На протяжении ряда лет Елизавета Всеволодовна вела научноисследовательскую работу в области географических проблем мирового хозяйства. В 1979 году в Ленинградском государственном университете ею была блестяще защищена, несмотря на 19 машинописных страниц отрицательного отзыва родной кафедры, докторская диссертация на тему «Аграрная география Англии и Уэльса». Защита проходила под председательством профессора С.Б. Лаврова. Научный интерес к географическим проблемам аграрной экономики капиталистической страны связан со стремлением на примере анализа взаимодействия природных, социально-исторических и экономических условий этого развития выявить фундаментальные связи универсальной системы «природа-общество-хозяйство», показать региональные аспекты рационального использования земли и охраны окружающей среды.

В работах Елизаветы Всеволодовны органически сочетались социально-экономический и природно-ресурсный аспекты комплексного анализа, показаны конкретные пути экономизации, гуманизации и экологизации географических исследований.

Елизавета Всеволодовна много внимания уделяла географии сельского хозяйства, населению и инфраструктуре сельской местности, 
прежде всего Поволжья, проводя совместные исследования с академическим институтом ИСЭП АПК АН СССР по этим проблемам. Многочисленные статьи и выступления Е.В. Мироновой на всесоюзных конференциях посвящены вопросам системного социально-экономического картографирования для целей планирования АПК, развития социальной инфраструктуры системы «город-село», исследования географических коллективов РСФСР и путей совершенствования их организации, влияния мелиоративного строительства на демографические процессы в Саратовской области, проблемам природоохранного районирования территории РСФСР.

Весомым был творческий вклад Елизаветы Всеволодовны в составление «Карты населения СССР на территории Саратовской, Волгоградской, Астраханской и Пензенской областей», опубликованной ГУГКом на 16 листах. Еще одним направлением ее научной деятельности было участие в работах с ЦЭНИИ Госплана СССР по исследованию городских поселений Саратовской и Волгоградской областей и с ИСЭП АПК РАН по «Социально-экономическим закономерностям развития регионального АПК (трудовые ресурсы, деморафическая ситуация, социальная инфраструктура в областях Нижнего Поволжья)». В итоге - 90 научных публикаций (в том числе три монографии).

Елизавета Всеволодовна долгое время занимала должность ученого секретаря (1972-1982 гг.), затем председателя (1982-2001 гг.) Головного совета по географическим наукам Министерства общего и профессионального образования. Она возглавляла Саратовский отдел Русского географического общества (1982-1998 гг.), активно выступала с лекциями.

Русское географическое общество оценило ее работу на посту председателя Саратовского отдела, присвоив ей звание почетного члена РГО.

Также Елизавета Всеволодовна занималась вопросами работы кафедры экономической географии СГУ, выполняемой по хоздоговору с ЦЭНИИ Госплана РСФСР, в помощь планированию развития средних и малых городских поселений Саратовской и Волгоградской областей, мероприятиями по рационализации территориальной системы культурно-бытового обслуживания населения этих областей, организацией в Поволжье отдыха и туризма, приоритетными направлениями географических исследований в вузах России, освещала вопросы рационального природопользования в научных исследованиях географических подразделений России.

За свою многолетнюю деятельность она отмечена грамотами, наградами и званием заслуженного работника высшей школы Российской Федерации (Указ Президента РФ от 5 августа 2000 г. № 1425 «О награждении государственными наградами Российской Федерации»).
За свою жизнь Елизавета Всеволодовна общалась со многими советскими и русскими учеными, в том числе с такими, как В.А. Анучин, Ю.Г. Саушкин, С.Б. Лавров, Д.И. Шашко, П.Е. Харитонов и В.Г Лебедев.

Она побывала в Китае, Индии, Египте, Турции, Германии, Франции, народно-демократических государствах Европы. Поработать приходилось в Москве, Ленинграде, Новосибирске, Иркутске, Томске, Якутске и во Владивостоке.

Е.В. Миронова - автор ряда методических пособий для студентов. Для молодежи она была добрым наставником, пользовавшимся заслуженным уважением. Будучи блестящим лектором, она внесла существенный вклад в подготовку научно-педагогических кадров и пропаганду географических знаний.

Елизавета Всеволодовна была настоящим русским интеллигентом. Она щедро делилась со студентами, аспирантами, коллегами и друзьями своими знаниями, теплом своей души, становясь от этого еще богаче. 22 ноября 2001 года Елизаветы Всеволодовны не стало. Сотни географов Саратова и других городов России и стран СНГ являются учениками Е.В. Мироновой, среди них немало кандидатов и докторов наук. Память о Елизавете Всеволодовне будет жить в ее учениках, в сердцах друзей и коллег.

\section{А.М. Демин}

\section{Основные публикации \\ Елизаветы Всеволодовны Мироновой}

1. Аграрные отношения в Великобритании и их влияние на развитие и размещение сельского хозяйства. Саратов: Изд-во Сарат. ун-та, 1966. 86 с.

2. К вопросу об интенсивности сельского хозяйства Англии // Вопросы географии сельского хозяйства: Сб. ст. Саратов: Изд-во Сарат. ун-та, 1968. 86 с.

3. Анализ факторов размещения сельского хозяйства Восточной Англии // Вопросы географии сельского хозяйства: Сб. ст. Саратов: Изд-во Сарат. ун-та, 1968. 86 с.

4. О факторах размещения сельского хозяйства Англии // Географические исследования в Саратовском университете: Сб. ст. / Гл. ред. Ю.В. Пешехонов. Саратов: Изд-во Сарат. ун-та, 1968. 270 с.

5. Аграрная география Англии и Уэльса. Саратов: Изд-во Сарат. ун-та, 1976. 222 с.

6. Схема характеристики экономического района. Саратов: Изд-во Сарат. ун-та, 1970. С. 88 (в соавторстве).

7. Очерк экономического развития Черновицкой области. Львов: Изд-во Львов. ун-та, 1958. 80 с.

8. География в вузах России. СПб., 1994 (редакция, соавторство).

9. Modern tendencies of development of agriculture regions of England and Wales // International Geographical congress. M., 1976. 